\title{
Pengaruh Perilaku Bullying terhadap Empati Ditinjau dari Tipe Sekolah
}

\author{
Isnaini Zakiyyah Arofa ${ }^{1}$, Hudaniah $^{2}$, Uun Zulfiana ${ }^{3}$ \\ ${ }^{1,2,3}$ Fakultas Psikologi, Universitas Muhammadiyah Malang \\ e-mail: 1izaarofa@gmail.com, ${ }^{2}$ hudaniah_hudaniah@yahoo.com, \\ ${ }^{3}$ zulfiana_uun@yahoo.com
}

\begin{abstract}
Abstrak. Semakin tahun perilaku bullying semakin meningkat baik secara verbal, fisik maupun psikologi. Bullying merupakan tindakan intimidasi yang dilakukan pihak yang lebih kuat terhadap pihak yang lebih lemah. Salah satu faktor dari perilaku bullying adalah kemampuan empati yang rendah. Tujuan penelitian ini adalah mengetahui apakah ada perbedaan perilaku bullying pada tipe sekolah dengan jenis kelamin sama dan sekolah dengan dua jenis kelamin setelah dikendalikan oleh empati. Metode yang digunakan dalam penelitian ini adalah kuantitatif uji ancova, dengan skala perilaku bullying dan skala empati Interpersonal Reactivity Index (IRI. Jumlah subjek sebanyak 385 santri perempuan dengan teknik cluster random sampling. Hasil penelitian menunjukkan adanya perbedaan perilaku bullying ditinjau dari tipe sekolah single sex school dan coeducational school setelah dikendalikan oleh empati nilai signifikansi sebesar 0,001 ( $\mathrm{p} \leq 0,05=0,001 \leq 0,05$ ). Besaraan sumbagan pengendalian empati terhadap perilaku bullying hanya sebesar 3,3\% sisanya dipengaruhi faktor lain yang tidak dijelaskan pada penulis pada penelitian ini.
\end{abstract}

Kata kunci : Perilaku bullying, empati, dan tipe sekolah

Abstract. More years of bullying behavior is increasing both verbally, physically and psychologically. Bullying is an act of intimidation by a stronger party against a weaker party. One factor of bullying behavior is low empathy. The purpose of this study was to find out whether there are differences in bullying behavior on single sex school type and coeducational schools after being controlled by empathy. The method used in this study is quantitative ancova test, with the scale of bullying behavior and empathy scale Interpersonal Reactivity Index (IRI) The number of subjects as much as 385 female santri with cluster random sampling technique.The results showed the differences in bullying behavior in the type of school single sex school And coeducational school after being controlled by empathy significance value of $0.001(p \leq 0,05=0,001 \leq 0,05)$. In addition, the contribution of empathy control to bullying behavior is only 3.3\%. The rest is influenced by other factors not explained to the authors in this study.

Keywords: Bullying behavior, empathy, and school type

Indonesia merupakan salah satu negara yang memiliki permasalahan tindak agresif yang tinggi seperti perilaku bullying pada remaja. Perilaku bullying tetap jadi isu penting di Indonesia. Perilaku bullying merupakan penggunaan kekerasan, ancaman, atau paksaan untuk menyalahgunakan atau mengintimidasi orang lain. Perilaku ini dapat menjadi suatu kebiasaan dan melibatkan ketidakseimbangan kekuasaan sosial atau fisik. 
Indonesia menjadi urutan pertama pada riset yang dilakukan oleh LSM Plan International dan International Center for Research on Women (IRCW) terkait bullying, riset ini dilakukan di beberapa negara dikawasan Asia. Sebanyak 84\% anak di Indonesia mengalami bullying di sekolah, sekitar 9000 anak terlibat dalam riset ini berusia 12-17 tahun (Qodar, 2015). Selain itu data dari Junior Chamber International (JCI) mencatat sekitar 40 persen pelajar di Kota Bogor, Jawa Barat, menjadi korban bullying. Sebanyak 30 sampai 40 persen dari korban bullying masih berusia SD, SMP, dan SMA. Bullying sering terjadi ketika seorang anak mempunyai kekurangan, baik secara fisik maupun mental (Ariefana, 2016)

Data KPAI mencatat anak berhadapan hukum mengalami peningkatan, total di periode bulan Januari-25 April 2016 ada 298 kasus. Ada meningkat 15 persen dibandingkan dengan 2015, sebanyak 298 kasus itu menduduki peringkat paling tinggi anak berhadapan dengan hukum. Diantaranya ada 24 kasus anak sebagai pelaku kekerasan fisik (Rismawan, 2016).

Terbentuknya perilaku bullying pada anak melalui proses-proses pembelajaran sosial atau pola-pola yang mempengaruhi satu sama lain dalam lingkungannya. Perilaku Bullying mulai tertanam sejak masih berusia dini sehingga perlu adanya upaya yang maksimal agar mencegah perilaku bullying tumbuh berkembang dirumah yang kemudian berlanjut ke sekolah (Priyatna, 2010). Menurut Lipskin (2008) kebanyakan seseorang menjadi pelaku bullying karena mereka menggalami pengalaman sebagai korban bullying, akibat dari menjadi korban teresebut pelaku memiliki keinginan balas dendam atas perbuatan yang ia dapatkan. Dari kasus seperti inilah perilaku bullying menjadi virus kemarahan dan dendam bermula, secara tidak langsung seorang yang akan menjadi pelaku akan menunggu saat ketika ia memiliki kekuasaan, kendali, dan kedudukan saat nantinya ia menjadi pelaku, korban bullying oleh pelaku ini ialah sesorang yang berstatus sosial rendah dalam kelompok, ataupun sebagai peserta calon anggota baru.

Sebagian orang mungkin berpendapat bahwa perilaku bullying tersebut merupakan hal sepele atau bahkan normal dalam setiap tahap kehidupan manusia. Faktanya, perilaku bullying merupakan perilaku tidak normal, tidak sehat, dan secara sosial tidak bisa diterima. Hal yang sepele pun kalau dilakukan secara berulang kali pada akhirnya dapat menimbulkan dampak serius dan fatal. Dengan membiarkan atau menerima perilaku bullying, kita berarti memberikan dukungan kepada pelaku bullying, menciptakan interaksi sosial yang tidak sehat dapat menghambat pengembangan potensi diri secara optimal (Wiyani, 2012).

Dampak bullying akan menghambat anak dalam mengaktualisasi dirinya karena perilaku bullying tidak akan memberi rasa aman dan nyaman, dan akan membuat para korban bullying meraa takutdan terintimidasi, rendah diri, tak berharga, sulit berkonsentrasi dalam belajar, serta tidak mampu untuk bersosialisasi dengan lingkungannya (Sejiwa, 2008).

Fenomena yang menyita perhatian di dunia pendidikan adalah penindasan di sekolah, baik yang dilakukan oleh guru terhadap siswa, maupun oleh siswa terhadap siswa 
lainnya. Bullying di sekolah adalah masalah seluruh dunia yang dapat memiliki konsekuensi seumur hidup negatif bagi siswa. Maraknya aksi tawuran dan kekerasan (bullying) yang dilakukan oleh siswa di sekolah yang semakin banyak menghiasi deretan berita di halaman media cetak maupun elektronik menjadi bukti telah tercabutnya nilainilai kemanusiaan. Tentunya kasus-kasus kekerasan tersebut tidak saja mencoreng citra pendidikan yang selama ini dipercayai oleh banyak kalangan sebagai sebuah tempat dimana proses humanisasi berlangsung, tetapi juga menimbulkan sejumlah pertanyaan dan bahkan gugatan dari berbagai pihak yang semakin kritis mempertanyakan esensi pendidikan disekolah (Wiyani, 2012).

Sekolah merupakan tempat yang paling banyak terjadi bullying, pada penelitian yang dilakukan oleh Nansel et.al.(2001) terhadap 15.600 siswa kelas 6 sampai 10 di Amerika. Hasilnya menunjukkan sekitar 17 persen dari mereka melaporkan menjadi korban bullying dengan frekuensi kadang-kadang hingga sering selama di sekolah, 19 persen mengaku melakukan bullying pada orang lain dengan frekuensi kadang-kadang hingga sering, dan 6 persen dari seluruh sampel menjadi pelaku dan korban bullying.

Selain itu, penelitian yang dilakukan oleh Putri et.al. (2015) ini bertujuan untuk mengetahui hubungan antara faktor internal dan eksternal yang berhubungan dengan perilaku bullying pada remaja. Data yang digunakan pada 83 siswa kelas 10 dan siswa kelas 11 di SMA Negeri 7 Pekanbaru menurutnya, terdapat hubungan antara jenis kelamin, tipe kepribadian, percaya diri, sekolah iklim dan rekan kelompok sosial di remaja. Terdapat korelasi antara variabel dengan intimidasi perilaku di kalangan remaja. Penelitian ini menyarankan setiap pemangku kepentingan khususnya guru untuk meningkatkan intimidasi kegiatan pencegahan, lanjut mengidentifikasi faktor-faktor yang menyebabkan munculnya perilaku bullying pada remaja di sekolah menengah atas.

Menurut penelitian yang dilakukan Saifullah, (2016) faktor yang menyebabkan bullying seperti faktor kelompok teman sebaya hal dinyatakan siswa-siswa pengaruh ikut-ikutan kelompok/grup pertemanan untuk berbuat usil dan mengolok-olok, selanjutnya karena faktor pola asuh orang tua yang kurang berperan ini dinyatakan para siswa disebabkan kurangnya attention (perhatian) orang tua dilingkungan keluarga dalam membentuk tingkah laku yang baik dan terakhir karena faktor iklim sekolah yang kurang mendukung, para siswa-siswi menyatakan bahwa sekolah banyak melakukan pembiaran dan kurang menindaklanjuti dalam hal ini disiplin sekolah masih bersifat lemah menyebabkan bullying ini dapat terjadi (Saifulah, 2015; \& Tumon, 2014). Selain itu faktor yang menjadi pemicu perilaku bullying pada remaja seperti jenis kelamin, tipe kepribadian anak, dan kepercayaan diri (Usman, 2013)

Selanjutnya faktor penyebab perilaku bullying yaitu empati. Empati juga berkontribusi penting dalam munculnya perilaku bullying. Berdasarkan hasil seminar ASEAN mengatakan perilaku bullying sangat berbahaya bagi anak-anak usia sekolah dikarenakan efek-efek negatif yang disebabkannya. Empati dapat menjadi sebuah solusi untuk mencegah perilaku bullying. Empati merupakan suatu kemampuan seseorang untuk merasakan keadaan emosional orang lain. Ketika seseorang individu mampu memahami kondisi emosional, mengenali perasaannya dan menempatkan diri berdasarkan sudut 
pandang orang lain, mereka lebih simpatik dan peduli, maka perilaku antisosial/bullying dapat dihindari (Fikrie, 2016). Kemudian pada penelitian eksperimen yang dilakukan Fatimatuzzahro (2016), dimana terapi empati yang dilakukan pada anak sekolah dasar mampu menurunkan perilaku bullying. Empati dengan perilaku bullying memiliki keterkaitan.

Berdasarkan penelitian yang dilakukan Rachmah (2014), diketahui bahwa alasan pelaku bullying melakukan perbuatan bullying yaitu dikarenakan faktor karakteristik korban, sikap korban, tradisi/budaya bullying di sekolah. Pelaku bullying melakukan bullying juga dikarenakan memiliki kemampuan empati yang rendah. Ketidakmampuan pelaku untuk berempati menyebabkan mereka kurang mampu untuk melihat dari sudut pandang orang lain, mengenali perasaan orang lain dan menyesuaikan kepeduliannya dengan tepat. Kurangnya empati dari pelaku menyebabkan pelaku kurang memahami kondisi korban, tidak peduli dengan korban dan cenderung melakukan tindakan kekerasan pada orang atau korban. Keterkaitan antara keduanya apabila anak tersebut memiliki empati yang tinggi maka untuk menjadi perilaku bullying akan semakin rendah. Pada dasarnya manusia semua manusia memilki sifat empati termasuk seseorang yang melakukan kesalahan. Ini bisa terjadi juga pada perilaku bullying mereka bisa saja masih memiliki empati. Empati telah dimiliki manusia sejak masih bayi, kemudian proses berkembangnya empati terjadi pada lingkungan atau pola asuh yang diberikan orang tua.

Menurut Davis (1983), empati adalah kemampuan seseorang untuk mengenal dan memahami emosi, pikiran serta sikap orang lain. empati mengandung dua konsep, yaitu melihat kerangka berpikir internal orang lain secara akurat dengan komponen-komponen yang saling berhubungan. Serta, dalam memahami orang lain tersebut, individu seolaholah masuk dalam diri orang lain sehingga bisa merasakan dan memahami orang lain tersebut (Taufik, 2012).

Menurut wawancara yang dilakukan oleh Ni'mah, (2014) kepada 20 santri terdapat berbagai masalah seperti: 1) Sebagian santri kurang peduli terhadap keadaan teman yang kurang dikenalnya, 2) Sebagian santri akan memberikan pertolongan apabila ada syarat tertentu, 3) Sebagian santri sering melakukan perbuatan yang merugikan orang lain, seperti: mencuri dan mengambil tanpa seijin yang memiliki 4) Sebagian santri kurang peduli dengan lingkungan sekitar. Ini juga berkaitan akan terjadinya perilaku bullying dan empati yang kurang karena kepedulian santri terhadap keadaan teman yang kurang dikenalnya.

Selain empati yang rendah yang berperan penting dalam terjadinya perilaku bullying menurut National Association of School Psychologist (NASP), (2012) salah satu faktor munculnya perilaku bullying adalah faktor sekolah, perilaku bullying berkembang pesat dalam lingkungan sekolah yang sering memberikan masukan negatif pada siswanya. Di dunia dan khususnya Indonesia ada dua jenis sekolah, ada sekolah yang terdiri dari siswa yang memiliki jenis kelamin sama dan ada juga dengan siswa yang berjenis kelamin campuran. Sekolah yang memiliki siswa yang terdiri dari jenis kelamin yang sama saja disebut dengan singlesex schools dan sekolah yang memiliki siswa berjenis kelamin campuran yaitu laki-laki dan perempuan disebut dengan coeducational schools. Beberapa 
penelitian di negara-negara lain mengenai single sex schools dan coeducational schools yang dikaitkan dengan berbagai persoalan antara lain, prestasi akademik, agresivitas, gender stereotype, kemampuan verbal, body image, hingga hubungan interpersonal (Pahlke et.al., 2014). Salah satu contoh sekolah di Indonesia yang memiliki siswa dengan jenis kelamin sama dan campuran adalah pondok pesantren.

Perilaku bullying tidak hanya terjadi di lingkungan sekolah formal saja melainkan dapat terjadi pada asrama atau pondok pesantren. Kasus bullying ini terjadi pada salah satu pondok pesantren di Jombang pada tahun 2016, seorang santri berumur 15 tahun meninggal dunia diduga akibat di keroyok oleh teman satu pesantren, dan di temukan luka lebam di seluruh tubuh korban (Ridwan, 2016).

Pesantren merupakan lingkungan yang mempunyai rutinitas kegiatan antara senior dan junior. Selain itu karakteristik lingkungan pesantren yang memiliki jumlah santri yang cukup banyak. Santri datang dari berbagai daerah yang memiliki perbedaan latar belakang budaya. Jumlah pembina santri dengan banyaknya santri yang tinggal di pesantren tidak seimbang. Letak bangunan komplek antara santri lama dengan yang baru tidak dipisahkan. Santri yang tinggal di pesantren tidak hal ini yang menjadi pemicu terjadinya bullying. Korban bullying mengaku bahwa ada rasa ketakutan, terancam, merasa tidak aman, sehingga hal ini mempengaruhi mental siswa selama berada di lingkungan tersebut. Dampak lanjut dari kejadian bullying pada siswa tidak mau masuk sekolah dan memutuskan untuk tidak melanjutkan sekolah (Yani et.al, 2016).

Bullying dapat terjadi di lingkungan sekolah maupun pesantren. Perilaku bullying di pesantren kebanyakan disebabkan oleh beberapa hal diantaranya mereka yang jauh dari pengawasan orang tua, berasal dari berbagai daerah yang memiliki adat dan budaya yang berbeda. Selain itu kurangnya pengawasan dari pihak pesantren serta banyaknya aturanaturan yang ditetapkan (Desiree, 2013). Pesantren atau pondok merupakan salah satu wadah untuk menanamkan dan mengajarkan nilai-nilai moral dan keislaman pada anak. Anak yang mengenyam pendidikan di pesantren berbeda dengan anak yang bersekolah di asrama karena setiap harinya anak diajarkan untuk menanamkan sikap berbudi luhur, sifat terpuji, dan diarahkan untuk berperilaku seperti Nabi Muhammad SAW. Tujuan dari pesantren yang menanamkan nilai keislaman pada anak didik bertentangan jika terjadinya tindakan bullying yang dilakukan oleh santri (Desiree, 2013).

Pada single sex school, para siswa berinteraksi dengan teman sebaya yang sejenis saja. Hal ini meningkatkan aktivitas yang sesuai dengan gender saja dan lama kelamaan perilaku anak juga dibeda-bedakan menurut gender saja (Martin \& Fabes, 2001). Misalnya, anak laki-laki bermain hanya dengan anak laki-laki saja maka dia akan menjadi lebih agresif dan bagi anak yang tidak mempunyai kontrol diri yang baik, maka dia lebih beresiko akan memiliki masalah dengan perilakunya. Selain itu, penelitian Faris dan Felmlee (2010), juga menunjukan bahwa pertemanan antar gender atau laki-laki dan perempuan, akan mengurangi agresifitas, dibandingkan dengan sekolah yang di dalamnya hanya terdapat pertemanan sesama jenis. 
Penelitian tentang proses kognitif dan sosial emosional merupakan salah satu mekanisme kontrol dari perilaku agresif individu diidentifikasi sebagai hal yang terkait dengan fenomena bullying (Kokkinos \& Kipritsi, 2012). Studi lain mengungkapkan bahwa anakanak yang agresif memiliki kekurangan dalam beberapa determinan sosial (berasal dari luar diri) yang berkaitan dengan perilaku agresif, kemampuan problem solving, selfefficacy, serta empati saat berinteraksi dengan orang lain. Empati memampukan individu untuk dapat membayangkan dan memahami pengalaman emosional individu lain. Kemampuan empati penting dalam perkembangan sosial dan emosional seseorang, dimana dapat mempengaruhi perilaku individu tersebut terhadap individu lain serta hubungan yang terjalin antar mereka.

Perilaku bullying dapat berhubungan dengan empati dapat dilihat dari faktor-faktor empati menurut Hoffman (2000) yaitu :

1. Sosialisasi, dengan adanya sosialisasi memungkinkan seseorang dapat mengalami sejumlah emosi, mengarahkan seseorang untuk melihat keadaanorang lain dan berpikir tentang orang lain. Perilaku bullying dapat ditemukan baik pada anak lakilaki maupun anak perempuan akan tetapi intensitasnya dipengaruhi oleh proses sosialisasi yang mereka terima, bukan karena adanya perbedaan tingkat keberanian dan ukuran fisik (Putri, Nauli, \& Novayelinda, 2015).

2. Mood and feeling, situasi perasaan seseorang ketika berinteraksi dengan lingkungannya akan mempengaruhi cara seseorang dalam memberikan respon terhadap perasaan dan perilaku orang lain. Setiap orang memiliki suasana hati gampang tersinggung, dan kadang kita tidak sadar mengapa kita merasa begitu. Hal ini juga dapat terjadi pada pelaku bullying, terkadang mereka melakukan sesuatu perencanaan dan maksud yang jelas, kadang tindakan-tindakan itu didorong oleh kekuatan-kekuatan di luar kesadaran mereka. Pengalaman-pengalaman traumatis mereka dimasa lalu mungkin berkitan dengan fisik, pelecehan, atau penghinaan. Perasaan-perasaan terpendam ini yang bisa membuat tiba-tiba meledak dalam bullying dan pelaku menjadi lepas kendali (Lipkins, 2008).

3. Situasi dan tempat, pada situasi tertentu seseorang dapat berempati lebih baik dibandingkan dengan situasi yang lain. Bullying berkembang dengan pesat dalam lingkungan sekolah yang sering memberikan masukan yang negatif pada siswanya misalnya, berupa hukuman yang tidak membangun sehingga tidak mengembangkan rasa menghargai dan menghormati antar sesama anggota sekolah (Rini, 2015)

4. Proses belajar dan identifikasi, apa yang telah dipelajari anak dirumah atau pada situasi tertentu diharapkan anak dapat menerapkannya pada lain waktu yang lebih luas. Perilaku bullying teman sebaya atau lingkungan yang memberikan pengaruh negatif dengan cara memberikan ide baik secara aktif maupun pasif bahwa bullying tidak akan berdampak apa-apa dan merupakan suatu hal yang wajar dilakukan (Rini, 2015)

5. Komunikasi dan bahasa, pengungkapan empati dipengaruhi oleh komunikasi (bahasa) yang digunakan seseorang. Perbedaan bahasa dan ketidakpahaman tentang komunikasi akan menjadi hambatan pada proses empati. Faktor komunikasi interpersonal siswa dengan orangtuanya. Siswa remaja yang tumbuh dalam keluarga yang menerapkan pola komunikasi yang negatif seperti sarcasm akan cenderung meniru kebiasaan tersebut dalam kesehariannya. Kekerasan verbal yang dilakukan 
orangtua kepada anak akan menjadi contoh perilaku. Hal ini akan diperparah dengan kurangnya kehangatan kasih sayangdan tiadanya dukungan dan pengarahan terhadap remaja, membuat siswa remaja memiliki kesempatan untuk menjadi seorang pelaku bullying (Usman, 2013).

6. Pengasuhan, lingkungan yang berempati dari suatu keluarga sangat membantu anak dalam menumbuhkan empati dalam dirinya. . Bullying dimaknai oleh anak sebagai sebuah kekuatan untuk melindungi diri dari lingkungan yang mengancam. Rendahnya keterlibatan dan perhatian orang tua pada anak juga bisa menyebabkan anak suka mencari perhatian dan pujian dari orang lain. Salah satunya pujian pada kekuatan dan popularitas meraka di luar rumah (Rini, 2015).

Pada sekolah dengan sesama jenis kelamin, para siswa berinteraksi dengan teman sebaya yang sejenis saja. Hal ini meningkatkan aktivitas yang sesuai dengan gender saja dan lama kelamaan perilaku anak juga dibeda-bedakan menurut gender saja (Martin dan Fabes, 2001). Misalnya, anak laki-laki bermain hanya dengan anak laki-laki saja maka dia akan menjadi lebih agresif dan bagi anak yang tidak mempunyai kontrol diri yang baik, maka dia lebih beresiko akan memiliki masalah dengan perilakunya (Fabes et.al, 1997). Berkaitan dengan perilaku bullying sekolah yang didalamnya terdapat dua jenis kelamin berbeda kemungkinan perilaku bullying lebih kecil daripada sekolah yang didalamnya terdapat satu jenis kelamin.

Berdasarkan uraian diatas bullying merupakan salah satu faktor seseorang melakukan bullying karena faktor sekolah yang kurang pengawasan dan empati yang kurang dan kurangnya mengenal santri satu sama lain. Dalam dunia pesantren perilaku bullying dapat terjadi karena adanya senioritas, sehingga dapat dirumuskan masalah yang akan diangkat dalam penelitian ini apakah hal ini bisa terjadi pada sekolah pesantren yang khusus dihuni pada salah satu jenis santri di sekolah single sex school atau pada sekolah pesantren yang coeducational schools karena pada dasarnya semua pesantren memiliki pendidikan ilmu agama dan moral yang sama, saling menghargai dan menyayangi sesama santri. Tujuan penelitian ini adalah mengetahui apakah ada perbedaan perilaku bullying ditinjau dari tipe sekolah dengan mengendalikan empati. Manfaat dari hasil penelitian diharapkan dapat memberikan informasi mengenai perilaku bullying siswa di single sex schools dan coeducational schools, memberikan masukan bagi mahasiswa psikologi yang membahas tentang perilaku bullying di sekolah/pesantren single sex school maupun coeducational schoolsdan empati di pesantren serta dapat menjadi referensi bagi penelitian psikologi selanjutnya.

\section{METODE}

Penelitian ini menggunakan jenis metode penelitian kuantitatif. Metode kuantitatif adalah metode penelitian yang berdasarkan pada filsafat positivisme yang digunakan untuk menguji populasi atau sampel tertentu dengan menggunakan statistik untuk menguji hipotesis yang sudah dibuat (Sugiyono, 2011). Populasi dari penelitian ini adalah santri kelas 7 \& 8 MTs/SMP yang berada di Pondok Pesantren di Malang, berjenis kelamin perempuan. Populasi dari pnelitian ini adalah santri MTs/SMP yang sekaligus pondok ditempat yang sama, sekolah atau pondok yang digunakan sebanyak 4 sekolah/pondok, 
tipe sekolah single sex school yaitu Pondok Pesantren Putri Ar-Rohmah sebanyak 195 orang, dan tipe sekolah co-educational school yaitu Pondok Pesantren Al-ittihad sebanyak 152 orang, MTs Al-Hidayah sebanyak 16 orang dan SMPi Sabilurrosyad 22 orang. Penentuan jumlah sampel di tentukan oleh tabel penentuan jumlah sampel yang di kembangkan oleh Isaac dan Michael, dengan taraf kesalahan 5\% maka pengambilan sampel setiap tipe sekolah. Teknik sampling yang digunakan adalah cluster random sampling yaitu, teknik sampling daerah yang digunakan untuk menentukan sampel bila obyek yang akan diteliti atau sumber data sangat luas, misalnya penduduk dari suatu negara, propinsi atau kabupaten (Sugiyono, 2012). Peneliti menggunakan cluster random sampling karena subjek yang digunakan adalah santri putri pondok pesantren di Malang kemungkinan data yang digunakan banyak untuk mengatasi hal tersebut peneliti hanya menggunakan beberapa sekolah, sekolah yang digunakan sebanyak 4 sekolah dan 3 dari sekolah tersebut adalah tipe sekolah co-educational school kemudian setelah menentukan keempat sekolah yang akan digunakan sebagai penelitian dilakukan pengambilan data secara random.

Skala adaptasi yang digunakan yaitu skala empati Interpersonal Reactivity Index (IRI), yang dikembangkan oleh Davis (1980). Sedangkan skala yang dibuat oleh peneliti sendiri dengan berdasarkan jenis perilaku bullying menurut (Coloroso, 2007) dan karakteristik dari Rigby (Astuti, 2008). Skala empati dengan 14 item valid dan indeks validitasnya berkisar antara 0,300 sampai 0,469 dan indeks reliabilitas pada skala empati adalah sebesar 0,765. Pada skala yang kedua yaitu skala bullying, diketahui terdapat 18 item valid dan indeks validitas berkisar antara 0,300 sampai 0,665 serta indeks reliabilitas pada skala bullying adalah 0,867.

Tahap terakhir yaitu analisis data dengan menggunakan software SPSS for windows 21.0. Data yang akan diujikan yaitu teknik penelitian menggunakan uji beda Independent Sample t-Test, uji hubungan dengan analisis korelasi product moment dan uji beda two way anova dengan analisis general linier model. Tujuan peneliti menggunakan independen sample t-test yaitu untuk mengetahui apakah ada perbedaan rata-rata (mean) antara dua populasi, dengan rata-rata dua sampelnya (Santoso, 2015). Kemudian tujuan peneliti menggunakan uji hubungan korelasi product moment adalah untuk mengetahui hubungan diantara populasi yang mempunyai dua varian (bivariate) (Santoso, 2015). Dan tujuan two way anova dengan analysis of covariance yaitu untuk menurunkan error variance dengan cara menghilangkan pengaruh variabel non kategorial yang kita percayai membuat bias non kategorial (Gozali, 2011).

\section{HASIL}

Subjek dalam penelitian ini adalah siswa MTs/SMP sekaligus santri di Pondok Pesantren dengan rentang usia 11-16 tahun. Total subjek dalam penelitian ini sebanyak 385 orang. Berikut ini penjelasan mengenai gambaran umum partisipan jika dilihat dari jenis kelamin, usia, kelas, sekolah, daerah asal, tempat tinggal, tipe sekolah, dan sekolah yang mana dilakukan dengan perhitungan statistik. 
Tabel 3.

Gambaran Umum Subjek Penelitian

\begin{tabular}{lccc}
\hline & Kategori & Frekuensi & Presentase \\
\hline Jenis Kelamin & Perempuan & 385 & $100 \%$ \\
Usia & 11 Tahun & 2 & $0,5 \%$ \\
& 12 Tahun & 59 & $15,3 \%$ \\
13 Tahun & 229 & $59,5 \%$ \\
14 Tahun & 84 & $21,8 \%$ \\
Kelas & 15 Tahun & 10 & $2,6 \%$ \\
Tempat Tinggal & 16 Tahun & 1 & $0,3 \%$ \\
Tipe Sekolah & 7 & 298 & $76,9 \%$ \\
& Asrama & 89 & $23,1 \%$ \\
Sekolah dengan jenis & 385 & $100 \%$ \\
kelamin sama & 195 & $50,6 \%$ \\
& Sekolah dengan dua & 190 & \\
& jenis kelamin & & $49,4 \%$ \\
Daerah Asal & MTs Al-Hidayah & 16 & \\
& MTs Al-Ittihad & 152 & $4,7 \%$ \\
& SMP Ar-Rohmah & 195 & $39,4 \%$ \\
& SMPi Sabilurrosyad & 22 & $50 \%$ \\
& Matal daerah lain & 217 & $5,9 \%$ \\
& & 168 & $43,6 \%$ \\
\hline
\end{tabular}

Berdasarkan pada tabel 3 diatas, diketahui sebanyak 59,5\% usia 13 usia merupakan usia terbanyak subjek penelitian, kemudian dari keseluruhan kelas 7 merupakan subjek terbanyak sebesar 76,9\%, sebanyak 39,4\% sekolah co-educational school yaitu sekolah MTs Al-Ittihad dan dari keseluruhan jumlah subjek sebanyak 56,4\% berasal dari kota Malang dari kedua tipe sekolah dan selebihnya dari luar kota Malang.

Tabel 4.

Deskripsi Kategori Bullying dan Empati

\begin{tabular}{lccc}
\hline \multicolumn{2}{c}{ Kategori Variabel } & Frekuensi & Persentase \\
\hline \multirow{3}{*}{ Bullying } & Rendah & 54 & $14 \%$ \\
& Sedang & 277 & $71,9 \%$ \\
\multirow{3}{*}{ Empati } & Tinggi & 54 & $14 \%$ \\
& & 57 & $14,8 \%$ \\
& Rendah & 267 & $69,4 \%$ \\
& Sedang & 61 & $15,8 \%$ \\
\hline
\end{tabular}


Berdasarakan hasil tabel 4 diatas, terdapat 277 subjek memiliki kategori sedang dengan persentase $71,9 \%$ pada skala perilaku bullying, dan pada skal empati terdapat 267 subjek dari 385 subjek juga berada pada kategori sedang dengan persentase sebesar 69,4\% .

Tabel 5.

Deskripsi Rata-rata Bullying dan Empati Berdasarkan Tipe Sekolah

\begin{tabular}{lccc}
\hline \multicolumn{1}{c}{ Tipe sekolah } & & Mean & Keterangan \\
\hline Sekolah dengan jenis & Bullying & 13,91 & Sedang \\
kelamin sama & Empati & 36,79 & Sedang \\
Sekolah dengan dua & Bullying & 14,88 & Sedang \\
jenis kelamin & Empati & 36,85 & Sedang \\
\hline
\end{tabular}

Berdasarkan hasil tabel 5, terdapat nilai rata-rata pada setiap tipe sekolah. Pada tipe sekolah singel sex school untuk perilaku bullying mean sebesar 13,91 yang merupakan kategori sedang dan untuk empati memiliki nilai mean 36,79. Sedangankan untuk tipe sekolah co-educational school juga memiliki kategori yang sama yaitu sedang dengan nilai mean 14,88 dan nilai mean empati sebesar 36,85 .

Berdasarkan uji deskriptif kenormalan data Kolmogorov-Smirnov diketahui nilai signifikansi skala bullying sebesar 0,108 dan skala empati 0,477 keduanya lebih besar dari 0,05 , bahwa kedua data skala yang di uji tersebut dapat dikatakan berdistribusi normal, sehingga dapat dilanjutkan dengan uji korelasi product moment, uji beda t-test dan uji beda ancova. Hasil uji linearitas diperoleh nilai signifikansi 0,923>0,05 yang menandakan terdapat hubungan yang linear secara signifikan antara variabel empati dan bullying. Berdasarkan hasil uji homogenitas nilai probabilitas sebagaimana tertera pada tabel diatas yaitu sebesar 0,338>0,05 maka varian kesalahan pada single sex school dan co-educational school pada bullying adalah homogen dengan demikian persyaratan sudah terpenuhi.

Tabel 6.

Analisis Uji Beda Ancova Pada Perilaku Bullying Ditinjau Dari Tipe Sekolah dan Dikendalikan Oleh Empati

\begin{tabular}{lccc}
\hline \multicolumn{1}{c}{ Kategori } & Sig & Keterangan & Kesimpulan \\
\hline Empati & 0,001 & $0,001<0,05$ & Signifikan \\
Tipe Sekolah & 0,160 & $0,176>0,05$ & Tidak Signifikan \\
\hline
\end{tabular}

Berdasarkan hasil data dari tabel 6, diketahui bahwa terdapat perbedaan perilaku bullying ditinjau dari tipe sekolah single sex school dan co-educational school setelah dikendalikan oleh empati dengan nilai signifikansi sebesar 0,001 $<0,05$ menandakan bahwa pernyataan tersebut siginifikan atau benar adanya. 


\section{DISKUSI}

Penelitian ini menunjukan adanya perbedaan perilku bullying ditinjau tipe sekolah setelah dikendalikan oleh empati. Hal ini dibuktikan adanya perbedaan perilaku bullying ketika tidak dikaitakan dengan empati, dan perilaku bullying dikaitkan dengan empati. Hal ini berdasarkan uji beda ancova. Berdasarkan hasil dari analisa data, diperoleh nilai signifikansi sebesar $0,001(\mathrm{p} \leq 0,05=0,001 \leq 0,05)$ yang berarti ada perbedaan perilaku bullying antara sekolah dengan jenis kelamin sama dan sekolah dengan dua jenis kelamin setelah dikendalikan oleh empati, artinya empati memliki pengaruh dalam pengendalian perilaku bullying. Hipotesa yang digunakan oleh peneliti adalah ada perbedaan perilaku bullying ditinjau dari tipe sekolah dengan mengendalikan empati. Berkaitan dengan empati beperilaku bullying dengan empati hal ini sejalan penelitian yang dilakukan oleh Mawarni, et al. (2015) bahwa ada hubungan negatif dan signifikan antara empati dengan school bullying. Semakin tinggi empati yang dimiliki seseorang, maka semakin rendah frekuensi melakukan school bullying pada remaja. Hasil penelitian ini juga dapat diperkuat dengan pendapat dari Baron dan Byrne (2003), yang menyatatakan bahwa empati berhubungan secara negatif dengan agresivitas. Penelitian Jolliffe dan Farington (2006) juga menyatakan, bahwa ada hubungan negatif yang signifikan antara empati dengan bullying, dan juga seseorang yang memiliki empati yang rendah kurang mampu merespon tekanan dan rasa ketidak nyamanan dari orang lain yang menjadi korban, mereka tidak mampu menghubungkan perilaku antisosial yang ia lakukan dengan reaksi emosional orang lain. Hal ini membuktikan bahwa hipotesa awal sesuai dengan hasil penelitian, yaitu terdapat perbedaan perilaku bullying yang signifikan antara kedua tipe sekolah antara sekolah dengan jenis kelamin sama dan sekolah dengan dua jenis kelamin setelah dikendalikan oleh empati, dengan kata lain jika perilaku bullying tidak dikendalikan dengan empati maka tidak ada perbedaan yang signifikan.

Selanjutanya hal ini mendukung pada hasil uji beda pada penelitian ini ditunjukkan pada nilai signifikansi sebesar 0,187 ( $\mathrm{p} \geq 0,05=0,187 \geq 0,05)$ yang dilakukan menggunakan uji beda $t$-test bahwa tidak ada perbedaan perilaku bullying jika hanya dibedakan pada tipe sekolah tanpa ada faktor lain. Penelitian di yogyakarta oleh Hardika (2009) menyatakan bahwa sekolah SMA dengan jenis kelamin sama lebih tinggi dari sekolah SMA dengan dua jenis kelamin. Penelitian terbaru lainnya juga mengungkapkan bahwa di Amerika perilaku bullying sekolah dengan dua jenis kelamin lebih tinggi dari sekolah dengan jenis kelamin sama (Johnson \& Gastic, 2014). Dari penelitian sebelumnya dapat disimpulkan bahwa perilaku bullying berpotensi akan terjadi dimana saja tanpa adanya perbedaan tipe sekolah dengan jenis kelamin sama dan dengan dua jenis kelamin. Hal ini mendukung hasil dari peneliti bahwa perilaku bullying tidak dapat dibedakan hanya berdasarkan tipe sekolah.

Menurut teori behaviourisme Aronfreed (dalam Taufik, 2012) empati di pelajari melalui proses pembelajaran di waktu anak-anak. Anak akan belajar bahwa perilaku-perilaku yang membahagiakan ataupun meringankan kesedihan orang lain membuat anak nyaman. Penelitian sejalan dengan teori ini dilakukan oleh Fatimatuzzahro, (2016) yaitu menggunakan penelitian ekperimen dimana terapi empati yang dilakukan pada anak sekolah dasar agar mampu menurunkan perilaku bullying. Ketika di usia yang masih dini 
anak dibiasakan untuk bagaiman berempati kepada orang lain ini berpengaruh kepada kehidupanya ketika remaja.

Selanjutnya Sari et.al. (2015) menggunakan pelatihan meningkatkan empati melalui psikoedukasi kepada pelaku bullying sebagai upaya untuk mengurangi bullying di sekolah menengah pertama, sehingga diharapakan pelatihan yang dilakukan dapat mengurangi marakanya tindakan bullying yang terjadi di sekolah.

Berdasarkan dari beberapa pendapat dan penelitian tersebut maka dapat dikatakan bahwa empati mempunyai peran penting untuk mengurangi perilaku bullying, semakin tinggi kemampuan empati, maka semakin rendah perilaku bullying seseorang. Sebaliknya, semakin rendah kemempuan empati pada seseorang, maka semakin tinggi perilaku bullying yang ada pada diri seseorang.

Besaraan pengaruh pengendalian empati terhadap perilaku bullying hanya sebesar 3,3\% nilai ini termasuk kecil dalam sebuah besaran pengaruh hal ini juga dapat mendukung bahwa hasil pada penelitian ini memiliki hubungan yang lemah ditunjukkan dengan nilai signifikansi $\mathrm{p}=-0,167>0,05$. Pada penelitian yang lain dilakukan bahwa tidak ada hubungan antara empati dan kencendrungan perilau bullying pada siswa karena adanya prediktor yang lebih kuat dari faktor lain (Panie, 2015). Hal ini sejalan dengan hasil yang menunjukan 3,3\% pengaruh empati dalam penelitian ini sisanya dipengaruhi faktor lain yang tidak dijelaskan pada penulis pada penelitian ini. Menurut penelitian yang dilakukan oleh Fithria dan Auli (2016) ada beberapa faktor penyebab bullying yaitu harga diri, kepribadian, keluarga, sekolah dan teman sebaya.

Mengenai beberapa faktor lain penyebab bullying penelitian yang dilakukan oleh Sandri (2015) bahwa ada pengaruh yang signifikan antara harga diri dengan perilaku bullying remaja. Selain itu juga penelitian yang dilakukan oleh Vintyana (2015) ada hubungan negatif antara harga diri dengan kecendrungan perilaku bullying pada siswa, artinya semakin tinggi harga diri seseorang maka semakin rendah perilaku bullying pada seseorang dan sebaliknya sjika semakin rendah harga diri yang dimiliki seseorang maka, perilaku bullying akan semakin tinggi. Hal ini sangat bisa dipahami bahwa ketika seseorang menganggap dirinya tidak berharga dan tidak menyayangi dirinya sendiri, maka seseorang dapat melakukan beragam tindakan yang justru merugikan dirinya sendiri dengan menjadi pelaku bullying, baik disadarinya maupun tidak.

Faktor selanjutnya pada faktor kepribadian, terdapat hubungan yang signifikan antara tipe kepribadian dengan perilaku bullying pada remaja Putri, Nauli \& Novayelinda (2015) dalam penelitian ini diperoleh bahwa remaja dengan tipe kepribadian ekstrovert, mayoritas memiliki perilaku bullying tinggi. tipe kepribadian ekstrovert cenderung lebih terbuka terhadap lingkungan, aktif, bersikap lebih agresif bahkan bertindak tanpa berfikir panjang dan cenderung impulsif. Berbeda dengan individu yang introvert cenderung tertutup terhdap lingkungan dan pasif. Sehingga umunya perilaku agresi atau bullying tampak pada individu yang memiliki tipe kepribadian ekstrovert. Penelitian lain dilakukan oleh Utomo (2013) pada siswa-siswi di SMA Salatiga ditemukan hasil bahwa jumlah siwa dengan kepribadian introvert dan ekstrovert sama-sama berpeluang untuk mengalami perilaku bullying maupun menjadi pelaku bullying. 
Keluarga merupakan faktor selanjutnya yang mendukung timbulnya perilaku bullying pola asuh merupakan hal penting yang berpengaruh dalam keluarga. Pada penelitian yang dilakukan oleh Putri (2017) mengenai pola asuh orang tua yang permisif menunjukkan bahwa terdapathubungan yang signifikan pola asuh permisif dengan perilaku bullying dengan sumbangan efektif sebesar $12,5 \%$ sedangkan sisanya dipengaruhi oleh faktor lainnya seperti iklim sekolah, kecerdasan emosi, peer group dan sebagainya. Hasil penelitian ini sejalan dengan apa yang di kemukakan oleh Coloroso (2007) salah satu faktor yang mempengaruhi bullying yaitu faktor keluarga. Pola asuh keluarga dan orang tua yang diterapkan seperti pola asuh permisif dan otoriter yang dapat memicu anak untuk memberontak. Pola asuh orang tua yang permissive adalah pola asuh orang tua yang bebas. Orang tua tidak mendorong anaknya untuk mentaati norma atau peraturan yang berlaku. Orang tua memberikan kebebasan kepada anak remajanya untuk mengaturkegiatannya sendiri, sejauh mereka masih dapat melaksanakannya. Anak diajar untuk menanggung konsekuensi dari hasil perbuatannya sendiri. Dengan pola asuh yang seperti ini, maka seorang anak cenderung mengembangkan perilaku agresi yang terbuka atau terangterangan. Pada penelitin lain juga mengungkapkan bahwa ada korelasi positif antara perilaku bullying dengan rendahnya keterampilan empati. Selain itu, hal ini ditentukan bahwa seiring meningkatnya keterampilan empati, ada penurunan perilaku bullying. Empati merupakan keterampilan bawaan yang bisa diperbaiki. Sementara keluarga memiliki peran utama dalam meningkatkan empati, lingkaran sosial anak di sekolah, teman dan keluarga dapat berkontribusi terhadap peningkatan (Ozkan \& Cifci, 2009).

Selanjutanya fakor sekolah yang dapat mempengaruhi timbulnya perilaku bullying, Sekolah merupakan salah satu lingkungan sosial yang menjadi tempat siswa menghabiskan sekitar 6-8 jam waktunya untuk memperoleh pendidikan formal serta terjadi interaksi dengan teman sebaya, guru, dan staf sekolah. Menurut penelitian yang dilakukan oleh Hanitis, Siswati, \& Setyawan (2015) penelitian menunjukkan adanya hubungan negatif antara persepsi terhadap iklim sekolah dan intensi bullying. Ketidakmampuan sekolah dalam menciptakan iklim sekolah yaitu berupa lingkungan sosial yang aman secara fisik maupun psikologis, proses pembelajaran yang kondusif, dukungan sosial yang tinggi, serta lingkungan fisik institusi yang layak, yang sehat dapat menimbulkan persepsi negatif terhadap iklim sekolah oleh siswa. Iklim sekolah yang dipersepsikan negatif oleh siswa dapat menimbulkan intensi berperilaku maladjustment, salah satunya yaitu bullying.

Kemudian faktor teman sebaya juga berpengaruh dalam berkembangnya suatu masalah dalam remaja. Pada penelitian yang dilakukan oleh Septiyuni, Budimansyah \& Wilodati (2015) menunjukkan bahwa siswa cenderung mempertimbangkan kesamaan yang dimiliki, sebagian besar siswa pernah melakukan perilaku bullying baik secara verbal, fisik maupun psikis, dan kelompok teman sebaya berpengaruh secara positif dan signifikan terhadap perilaku bullying siswa. Kelompok teman sebaya sebagai lingkungan sosial bagi remaja (siswa) mempunyai peranan penting bagi perkembangan kepribadiannya, salah satunya untuk mengembangkan identitas diri serta 
mengembangkan kemampuan komunikasi interpersonal dalam pergaulan dengan kelompok teman sebaya.

Berdasarkan pada subjek penelitian yang merupakan santri pondok pesantren, pondok pesantren merupakan tempat dimana seorang belajar lebih pada nilai agama, moral dan perilaku. Meskipun memiliki perbedaan pertemanan dalam sekolah namun kedua pondok ini memiliki peraturan dan pendidikan yang sama dalam pembentukan moral dan perilaku. Sehingga dalam berprilaku individu kedua tipe sekolah ini tidak memiliki perbedaan yang signifikan karena adanaya pendidikan nilai agama, moral dan perilaku yang sangat dapat mengontrol perilaku negatif yang mungkin saja akan muncul berlebihan pada santri. Ini sejalan dengan penelitian mengenai bullying tidak ada perbedaan perilaku bullying antara sekolah dengan jenis kelamin sama dan sekolahdengan dua jenis kelamin jika tidak dikendalikan oleh faktor apapun.

Penelitian yang telah dilakukan ini juga tidak lepas dari berbagi kelemahan. Kelemahan penelitian ini hanya mengungkap satu jenis kelamin saja yaitu perempuan dan sekolah yang diteliti merupakan sekolah asrama berbasis agama yaitu pondok pesantren, mungkin untuk penelitian selanjutnya dapat meneliti jenis kelamin laki-laki dan sekolah yang digunakan adalah sekolah formal tanpa asrama maupun pondok pesantren yang dapat digunakan sebagai referensi pelengkap untuk penelitian selanjutnya.

\section{SIMPULAN DAN IMPLIKASI}

Berdasarkan hasil penelitian ini, dapat disimpulkan bahwa terdapat perbedaan yang signifikan terhadap perilaku bullying ditinjau dari tipe sekolah dengan mengendalikan empati. Besaran nilai signifikansi sebesar $0,001(\mathrm{p} \leq 0,05=0,000 \leq 0,05)$ yang berarti ada perbedaan perilaku bullying antara sekolah dengan jenis kelamin sama dan sekolah dengan dua jenis kelamin setelah dikendalikan oleh empati dan tidak ada perbedaan yang signifikan pada perilaku bullying antara tipe sekolah sekolah dengan jenis kelamin sama dan sekolah dengan dua jenis kelamin, perilaku bullying dapat terjadi dimana saja tanpa harus mengaitkan dengan tipe sekolah dan adanya hubungan antara perilaku bullying dan empati walapun nilai hubungan bersifat lemah.

Implikasi dari penelitian ini yaitu, untuk setiap orang tua dapat mencegah atau menangani perilaku bullying pada putra-putrinya dengan cara mengembangkan empati dalam kehidupan sehari-hari serta dapat menerapkan pola untuk saling menghargai satu sama lain. Kepada sekolah diharapkan guru dapat membiasakan bagaimana menciptakan suasana saling peduli membiasakan saling berempati kepada sesama teman sehingga perilaku bullying yang terjadi dapat berkurang bahkan semakin kecil potensinya. Dengan demikian diharapkan terputusnya rantai bullying dalam dunia pendidikan. Bagi penelitian selanjutanya disarankan untuk melakukan penelitian dengan jenis kelamin laki-laki agar dapat diketahui hasil untuk membandingkan bagaimana mengendalikan menggunakan faktor lain agar memperluas apa saja faktor yang dapat mengendalikan perilaku bullying agar kedepannya tidak semakin berkembang di dunia pendidikan maupuan masyarakat. 


\section{REFERENSI}

Ariefana, P. (2016). 40 persen pelajar di kota bogor korban "bullying". Diakses pada Januari 2017 dari http://www.suara.com/news/2016/06/16/034922/40-persenpelajar-di-kota-bogor-korban-bullying

Astuti, P. R. (2008). Meredam bullying 3 cara efektif meredam, K.P.A (Kekerasan Pada Anak). Jakarta: Grasindo.

Azwar, S. (2015). Metode penelitian. Yogyakarta: Pustaka Pelajar.

Baron, R.A. \& Byrne, D. (2003). Psikologi sosial jilid 2. Jakarta : Erlangga.

Basyirudin, F. (2010). Hubungan antara penalaran moral dengan perilaku bullying para santri madrasah aliyah pondok pesantren Assa'adah Serang Banten. Skripsi. Tidak Diterbitkan. Fakultas Psikologi. Unversitas Islam Negeri (UIN) Syarif Hidayatullah Jakarta.

Coloroso, B. (2007). Stop bullying (memutus rantai kekerasan anak dari prasekolah hingga $S M U$ ). Jakarta: Serambi.

Davis, M.H. (1980). A multidimensional approach to individual differences in empathy. Catalog of Selected Documents in Psychology, 10, 1-19.

Delwis, \& Putri, N. (2014). Perbedaan kecerdasan sosial siswa single sex schools dan coeducational schools di kota Padang. Skripsi. Tidak diterbitkan. Universitas Sumatera Utara.

Desiree .(2013). Bullying di pesantren (studi deskriptif di pesantren X Depok ). Skripsi Psikologi. Fakultas Ilmu Sosial dan Politik. Universitas Indonesia.

Fabes, R.A, Shepard, S.A, Guthrie, I.K, \& Martin, C.L. (1997). Roles of temperamental arousal and gender segregated play in young children's social adjustment. Developmental Psychology, 33, 693-702.

Faris, R., \& Felmlee, D. (2010). Journal status struggles: network centrality and gender segregation in same- and cross-gender aggression. American Sociological Review, 76. 48-73.

Fatimatuzzahro, A. (2016). Efektivitas terapi empati untuk menurunkan perilaku bullying pada anak usia sekolah dasar. Skripsi. Tidak Diterbitkan. Universitas Islam Negeri Sunan Kalijaga Yogyakarta.

Fikrie. (2016). Peran empati dalam perilaku bullying. Seminar Asean. Psikologi Forum UMM. Universitas Muhammadiyah Malang. 
Fithria \& Auli, R. (2016). Faktor-faktor Yang Berhubungan Dengan Perilaku Bullying. Idea Nursing Journal. 7, (3).

Hanitis, P. M., Siswati \& Setyawan, I. (2015). Hubungan Antara Persepsi Terhadap Iklim Sekolah Dengan Intensi Bullying Pada Siswa SD Islam X. Fakultas Psikologi. Universitas Diponegoro. Jurnal Empati. 4, (1), 134-141.

Gozali, I. (2011). Aplikasi analisis multivariate dengan program IBM SPSS 19. Semarang: Badan Penerbit Universitas Diponegoro.

Hardika, I., R. (2009). Perbedaan kecendrungan perilaku bullying antara sekolah menengah atas homogen dan heterogen di Yogyakarta. Skripsi. Universitas Sanata Dharma Yogyakarta.

Hendrastomo, G. (2012). Homogenisasi pendidikan: potret eksklusifitas pendidikan modern. http://staff.uny.ac.id/sites/default/files/lain-lain Diakses pada Maret 2017.

Hudaniah \& Dayakisni, T. (2012). Psikologi sosial. Malang: UMM Press.

Hoffman, \& Martin (2000). Empathy and moral development: implication for caring and justice. Cambridge. Cambridge University press.

Howe, D. (2015). Empati, makna dan pentingnya. Yogyakarta. Pustaka Pelajar.

Jhonson, D., \& Gastic, B. (2014). Patterns of bullying in single-sex school. Sexuality Research and Social Policy. 11, (2) 126-136.

Jolliffe, D. \& Farrington, D. P. (2006). Examining the Reliationship Between Low Empathy and Bullying. Journal Aggressive Behavior. University of Cambridge, England. London. 32, 540-550.

Kokkinos, C.M., \& Kipritsi, E. (2012). The relationship between bullying, victimization, trait emotional intelligence, self-efficacy and empathy among preadolescents. Social Psychology Education, 15, 41-58.

Kpai. (2016). Mengejutkan! bullying di sekolah meningkat, jadi perhatian serius Jokowi dan KPAI. Diakses pada januari 2017 dari http://www.kpai.go.id/berita/mengejutkan-bullying-di-sekolah-meningkat-jadiperhatian-serius-jokowi-dan-kpai/.

Lipkins, S. (2008). Menumpas kekerasan pelajar \& mahasiswa menghentikan perpeloncoan di sekolah/kampus. Tangerang Banten: INSPIRITA Publishing

Martin, C.L. \& Fabes, R.A. (2001). Journal the stability and consequence of same sex peer interactions. Developmental Psychology. 37, (3) 431-446. 
Mawarni, R., Hardjono, \& Andayani, T.R. (2015) Hubungan Antara Mencari Sensasi dan Empati dengan School Bullying pada Remaja Putra Kelas X dan XI di Madrasah Mu'allimin Muhammadiyah Yogyakarta. Skripsi. Universitas Sebelas Maret.

Mestre, M.V., Samper, P., Frías, M.D., \& Tur, A.M. (2009). Are women more empathetic than men? a longitudinal study in adolescence. The Spanish Journal of Psychology by The Spanish Journal of Psychology 2009. 12, (1), 76-83.

Nansel, T.R., Overpeck, M., Pilla, R.S., Ruan, W.J., Simon, M.B. \& Scheidt, P. (2001). Bullying behavior among US Youth. JAMA. 285, 2094-2100.

NASP. (2012). Position statment : bullying prevention and intervention in school. 4340 East West Higway, Ste.

Nurcahyono, A. (2013). Perbedaan empati pada siswa laki-laki dan perempuan pada siswa kelas IX smp negeri 3 Salatiga. Skripsi. Universitas Kristen Satya Wacana. Salatiga.

Ozkan, Y., \& Cifci, E.G. (2009). The effect of empathy level on peer bullying in school. Journal Humanity \& Social Sciences. 4 (1) : 31-38.

Pahlke, E., Hyde, J.S.,\& Allison, C.M. (2014). Journal the effect of single-sex compared with coeducational schooling on students performance and attitudes: A Meta- Analysis.

Panie, A. M. (2015). Hubungan antara empati dengan kecendrungan perilaku bullying pada siswa di SMA Negeri 1 Kupang Timur. Skripsi. Universitas Kristen Satya Wacana. Salatiga.

Priyatna, A. (2010). Lets end bullying: memahami, mencegah \& mengatasi bullying. Jakarta: PT. Elex Media Komputindo.

Putri, H.N., Nauli, F.A., \& Novayelinda, R. (2015). Faktor-faktor yang berhubungan dengan perilaku bullying pada remaja. JOM. 2, (2).

Putri, W. K. (2017). Hubungan pola asuh permisif dengan perilaku bullying di SMPN 5 Samarinda. Skripsi. Tidak diterbitkan. Fakultas Psikologi. Universitas 17 Agustus 1945 Samarinda.

Qodar, N. (2015). Survei ICRW: 84\% anak indonesia alami kekerasan di sekolah. Diakses pada Maret 2017 dari : http://news.liputan6.com/read/2191106/surveiicrw-84-anak-indonesia-alami-kekerasan-di-sekolah.

Rachmah, D. N. (2014). Empati pada pelaku bullying. Jurnal Ecopy. 1, (2). 
Ridwan, M. (2016). Santri asal jember tewas dikeroyok di pondok pesantren jombang. Diakses pada Maret 2017 dari www.lensaindonesia.com/2016/03/01/santri-asaljember-tewas-dikeroyok-di-pondok-pesantren-jombang.html.

Rini, M. S. (2015). Hubungan antara faktor kemampuan berinteraksi sosial dengan perilaku bullying di Malang. Skripsi. Tidak diterbitkan. Universitas Muhammadiyah malang.

Rismawan, I. (2016). KPAI: Angka kekerasan terhadap anak meningkat. Diakses pada Januari 2017 dari http://www.tribunnews.com/nasional/2016/05/06/kpai-angkakekerasan-terhadap-anak-meningkat.

Saifullah, F. (2016). Hubungan antara konsep diri dengan bullying pada siswa-siswi smp (SMP Negeri 16 Samarinda).Jurnal Psikologi. 4, (2) 200- 214.

Salim, M. \& Ginanjar, A. S. (2013) Hubungan antara empati dan perilaku bullying dan defending terhadap siswa dengan ASD. Skripsi. Tidak diterbitkan. Fakultas Psikologi. Unversitas Indonesia.

Sandri, R. (2015). Perilaku bullying pada remaja panti asuhan ditinjau dari kelekatan dengan teman sebaya dan harga diri. Jurnal Psikologi Tabularasa. 10, (1) 43-57

Santoso, S. (2015). Menguasai SPSS 22 from basic to expert skills. Jakarta : PT Elex Media Komputindo.

Sari, H. N., Joefiani, P. \& Siswandi, A. G. P. (2015). Pelatihan meningkatkan empati melalui psikoedukasi kepada pelaku bullying sebagai upaya mengurangi bullying di sekolah menengah pertama. Tesis. Universitas Padjajaran.

Sejiwa. (2008). Bullying : mengatasi kekerasan di sekolah dan lingkungan sekitar anak. Jakarta : PT Grasindo.

Septiyuni, D. A., Budimansyah, D., \& Wilodati. (2014). Pengaruh teman sebaya (peer group) terhadap perilaku bullying siswa di sekolah. Jurnal Sosietas. 5, (1).

Smyth, E. (2010). Single-sex education: what does research tell us?. revue française de pédagogie. 171, 47-55.

Stein, S. J. \& Book, H. E. (2002). Ledakan EQ 15 prinsip dasar kecerdasan emosional meraih sukses. Bandung: Mizan Media Utama.

Sugiyono. (20112). Metode penelitian administrasi. Bandung: Alfabeta.

Sullivan, A., Joshi, H., \& Leonard, D. (2011). Single sex schooling and labour outcomes. Oxford Review Education, 37. 311-332.

Taufik. (2012). Empati: pendekatan psikologi sosial. Jakarta: Rajawali Pers. 
Tumon, M. B.A. (2014). Studi deskriptif perilaku bullying pada remaja. Jurnal Psikologi. $3(1)$.

Usman, I. (2013). Kepribadian, komunikasi, kelompok teman sebaya, iklim sekolah dan perilaku bullying. Jurnal Humanitas. 10, (1).

Usman, I. (2013). Perilaku bullying ditinjau dari peran kelompok teman sebaya dan iklim sekolah pada siswa sma di kota Gorontalo. Skripsi. Universitas Negeri Gorontalo.

Utomo, A. B. (2013). Perbedaan tipe kepribadian ekstrovert dan introvert didalam frekuensi terkena bullying (studi kepada siswa SMA Negeri 3 Salatiga). Skripsi. Tidak Diterbitkan. Universitas Kristen Satya Wacana Salatiga.

Vintyana, S. R. A. (2015). Hubungan antara harga diri dan kecendrungan perilaku bullying pada siswa SMP Kristen 1 Magelang. Skripsi. Tidak Diterbitkan. Universitas Kristen Satya Wacana Salatiga.

Wimmer, S. (2009). Views on gender differences in bullying in relation to language and gender role socialisation. Griffith Working Papers in Pragmatics and Intercultural Communication. 2, (1), 18-26.

Wiyani, N.A. (2012). Save our children from school bullying. Jogjakarta: Ar-Ruzz Media.

Yani, A. L., Winarni, I., Lestari, R. (2016). Eksplorasi fenomena korban bullying pada kesehatan jiwa remaja di pesantren. Jurnal Ilmu Keperawatan. 4, (2). 